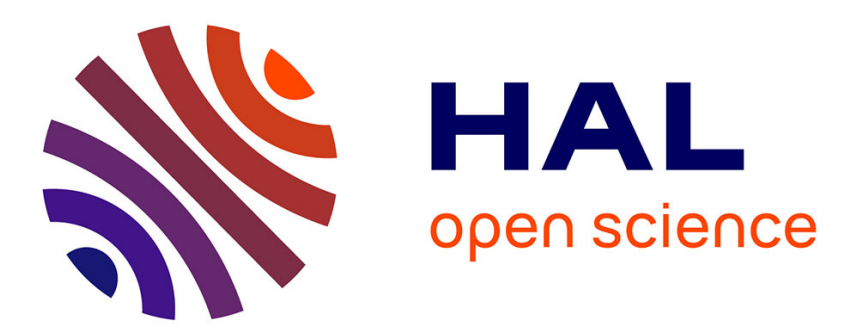

\title{
Effect of palladium-based undercoat on the formation, structure and properties of diffusion aluminide coatings
}

\author{
P. Steinmetz, S. Alpérine, P. Josso, J. Claude
}

\section{To cite this version:}

P. Steinmetz, S. Alpérine, P. Josso, J. Claude. Effect of palladium-based undercoat on the formation, structure and properties of diffusion aluminide coatings. Journal de Physique IV Proceedings, 1993, 03 (C9), pp.C9-499-C9-509. 10.1051/jp4:1993953 . jpa-00252393

\section{HAL Id: jpa-00252393 https://hal.science/jpa-00252393}

Submitted on 1 Jan 1993

HAL is a multi-disciplinary open access archive for the deposit and dissemination of scientific research documents, whether they are published or not. The documents may come from teaching and research institutions in France or abroad, or from public or private research centers.
L'archive ouverte pluridisciplinaire HAL, est destinée au dépôt et à la diffusion de documents scientifiques de niveau recherche, publiés ou non, émanant des établissements d'enseignement et de recherche français ou étrangers, des laboratoires publics ou privés. 


\title{
Effect of palladium-based undercoat on the formation, structure and properties of diffusion aluminide coatings
}

\author{
P. Steinmetz $\left({ }^{1}\right)$, S. Alpérine $\left({ }^{2}\right)$, P. Josso $\left({ }^{2}\right)$ and J.M. Claude $\left({ }^{1}\right)$
}

(1) Laboratoire de Chimie du Solide Minéral, Faculté des Sciences de l'Université de Nancy I, BP. 239, 54506 Vandoeuvre cedex, France

$\left(^{2}\right)$ ONERA, Direction Scientifique des Matériaux, BP. 72, 92322 Chatillon cedex, France

\begin{abstract}
Coatings with Pd-Ni predeposit alloys have been processed using various aluminizing treatments: low and high activity cements, pack and vapor phase coatings. Their metallurgical structure has been investigated with a special emphasis on the repartition of the various metallic elements throughout the coating section. During a first step, aluminizing of the palladium rich underlayer takes place, followed by simultaneous diffusion of nickel and aluminum through this first aluminized layer. Palladium concentration profiles - which significantly differ when using L.A. or H.A. cements - provide qualitative indications concerning the overall "activity" of aluminum in the aluminizing process. Palladium, if present at a sufficient level, enhances Al diffusion in the beta phase. In the case of L.A. processes, a consequence of this increase of $\mathrm{Al}$ diffusion flux is the location of $\mathrm{NiAl}$ reaction zone inside the coating.
\end{abstract}

\section{Introduction.}

A constant problem for turboengine manufacturers is the need to increase components lifetime by applying efficient protective coatings. Among the different families of high temperature oxidation and hot corrosion resistant coatings, modified aluminides are undoubtedly of high interest, due to their good performances, which compare well to those of more expensive overlays. Also, they can be processed very easily.

The modifying element is pre-deposited on the surface of the parts to protect by an appropriate technique (GVD, electroplating, etc.). This preliminary treatment is followed by a classical aluminizing process. Today, the highest efficiency is achieved with a noble metal modifying element such as platinum, which drastically increases the H.T. oxidation and hot corrosion resistance of aluminide coatings $[1,7]$. The main limitations of platinum modified aluminide coatings are their poor ductility, due to the presence in their structure of a $\mathrm{PtAl}_{2}$ brittle phase and their elevated price. Because of this, renewed interest has been found in replacing platinum metal in the coatings with palladium [8,9]. Palladium has proved to be a good substitute to platinum and Pd modified aluminide coatings are now on their way to be used on an industrial basis for some aeronautic applications. Besides, most of the studies devoted to Pd modified aluminides have been focused on the influence of palladium on the high temperature behavior of such coatings; the mechanisms of formation of the coatings have not been fully considered until now.

Information on the processes which lead to the coatings formation are nevertheless of prime importance, if one wishes to tailor the whole coating procedure according, for instance, 
to a given superalloy substrate. Moreover, the role played by palladium in coating elaboration processes can provide some insights on how it enhances superalloys high temperature resistance.

In the present study, various processing routes are described, all leading to palladium modified aluminide coatings. The metallurgical structures of the coatings and palladium distribution are being interpreted in the light of the results of a more fundamental study devoted to the determination of the Ni-Pd-Al phase diagram.

\section{Experimental procedure.}

2.1 COATING DEPOSITION PROCESS. - Two types of superalloys have been coated with palladium modified aluminides: single crystal and conventional equiaxed alloys. Their composition in weight percent are detailed in table $I$.

Table I.

\begin{tabular}{|c|c|c|c|c|c|c|c|c|c|}
\hline Alloy & $\mathrm{Ni}$ & Co & $\mathrm{Cr}$ & $\mathrm{Ti}$ & $\mathrm{Al}$ & Mo & $\bar{W}$ & $\mathrm{Ta}$ & $\bar{C}$ \\
\hline $\begin{array}{l}\text { Single Crystal alloys } \\
\text { SRR } 99\end{array}$ & base & 5 & 8.5 & 2.2 & 5.5 & - & 9.5 & 2.8 & $<0.05$ \\
\hline AM1 & base & 5 & 8.5 & 2.2 & 5.16 & 2.2 & 5.66 & 8.17 & $<0.05$ \\
\hline $\begin{array}{l}\text { Equiaxed alloys } \\
\text { IN } 100\end{array}$ & base & 15 & 10 & 4,7 & 5,5 & 3 & - & - & 0.15 \\
\hline RENE 80 & base & 9.5 & 14 & 5 & 3 & 4 & 4 & - & 0.17 \\
\hline $\mathrm{C} 1023$ & base & 10 & 15 & 3.6 & 4 & 8.5 & - & - & 0.16 \\
\hline
\end{tabular}

Before aluminizing, a Pd/Ni alloy ( $80 / 20$ by weight) undercoat was applied on the substrates, via one of the two following processes:

- electroplating, with a commercial Pd/Ni solution (Engelhardt Pallnic "Aeronautics special")

- electroless palladium plating $(6 \mu \mathrm{m})$, followed by pure nickel electroless plating $(2 \mu \mathrm{m})$.

The compositions and conditions of use of the electroless Pd and Ni baths have been described elsewhere [10].

In both cases, the substrates were sand blasted, then carefully degreased, before $\mathrm{Pd} / \mathrm{Ni}$ coating. After coating, they were annealed under vacuum, two hours at $850^{\circ} \mathrm{C}$. In these conditions, interdiffusion enhances the adherence of the coatings to the substrate. Moreover, in the case of the electroless processes, it favours $\mathrm{Pd}$ and Ni superficial alloying, leading to a composition close to that obtained with the electrolytic process.

The undercoat composition has been selected to limit hydrogen incorporation in palladium during the aluminizing treatment. The very high solubility of hydrogen in pure palladium can indeed lead to catastrophic failure of the aluminide layer, due to blistering, as was observed in the case of pure palladium underlayers [8].

Palladium-containing samples were then aluminized, using standard low activity and high activity pack-cementation processes [11] and low activity vapour phase cementation [12]. The aluminizing conditions are listed in table II. 
Table II.

\begin{tabular}{|l|l|l|l|}
\hline & $\begin{array}{l}\text { High activity } \\
\text { (inward) }\end{array}$ & $\begin{array}{l}\text { Low activity } \\
\text { (outward) }\end{array}$ & $\begin{array}{l}\text { Vapour phase } \\
\text { (outward) }\end{array}$ \\
\hline $\begin{array}{l}\text { Cement } \\
\text { composition }\end{array}$ & $\begin{array}{l}\text { Al2O3 (diluent) } 50 \mathrm{wt} \% \\
\text { Aluminum 32.5 } \mathrm{wt} \% \\
\text { Chromium } 17.5 \mathrm{wt} \%\end{array}$ & $\begin{array}{l}\text { Al2O3 (diluent) } 50 \mathrm{wt} \% \\
\text { Aluminum } 7.5 \mathrm{wt} \% \\
\text { Chromium } 42.5 \mathrm{wt} \%\end{array}$ & $\begin{array}{l}\text { Aluminum } \\
30 \mathrm{wt} \% \\
\text { Chromium } \\
70 \mathrm{wt} \%\end{array}$ \\
\hline Temperature & $\begin{array}{l}700^{\circ} \mathrm{C} \\
\text { Post-treatment at } 1085^{\circ} \mathrm{C}\end{array}$ & $1050^{\circ} \mathrm{C}$ & $1150^{\circ} \mathrm{C}$ \\
\hline Duration & $\begin{array}{l}7 \mathrm{~h} \\
\text { Post-treatment:8h }\end{array}$ & $16 \mathrm{~h}$ & $3 \mathrm{~h}$ \\
\hline Activator & NH4Cl & NH4Cl & NH4F \\
\hline Atmosphere & Hydrogen & Hydrogen & Argon \\
\hline
\end{tabular}

\subsection{STUDY OF THE TERNARY Ni-Pd-Al PHASE DIAGRAM.}

Synthesis of ternary alloys. - Ternary Ni-Pd-Al alloys were synthetized by H.F. melting under argon of appropriate mixtures of the constituting elements. Nickel, aluminum and palladium used for this operation were high purity materials, and were available under the form of rods or crystals.

The ingots obtained after cooling of the melted alloys were equilibrated by annealing $72 \mathrm{~h}$ at $1100{ }^{\circ} \mathrm{C}$ under argon. Some of them were also equilibrated afterwards at $850{ }^{\circ} \mathrm{C}$ during 14 days. These samples were then embedded in an epoxy resin, polished and analyzed by microprobe to control their composition and homogeneity. Microhardness measurements were also done on the cross sections.

\section{Results.}

Unless stated otherwise all concentration data are in atomic percent.

3.1 ALUMINIZING TREATMENTS. - With the different alloys and aluminizing conditions studied, the results obtained are very similar and do not depend on the method used to elaborate the $\mathrm{Pd} / \mathrm{Ni}$ undercoat (electrolytic or electroless). Figures 1 to 3 which correspond to the different types of cementation, show indeed that the structure of the coatings are approximately identical, whatever the aluminizing process. These observations indicate that palladium do not modify fundamentally coatings formation mechanisms, since in all cases, a two-layer structure very similar to those observed in classical aluminizing treatments is being observed. The external layer is composed of a single phase with the $\beta$-NiAl crystallographic structure, and is the richest in palladium. In the innermost third of the coating, which constitutes the second layer, precipitates of $\sigma$ phases and carbides can be observed in a $\beta$-NiAl type matrix which has dissolved several per cent of palladium. For a given cementation process, this structure is quite independant on the composition of the superalloy substrate. The only difference lies in the composition of the internal layer which is determined by the reaction:

$$
\text { Superalloy } \rightarrow \beta-\mathrm{NiAl}+\mathrm{Ni}^{*}+\mathrm{Co}^{*}+\ldots
$$




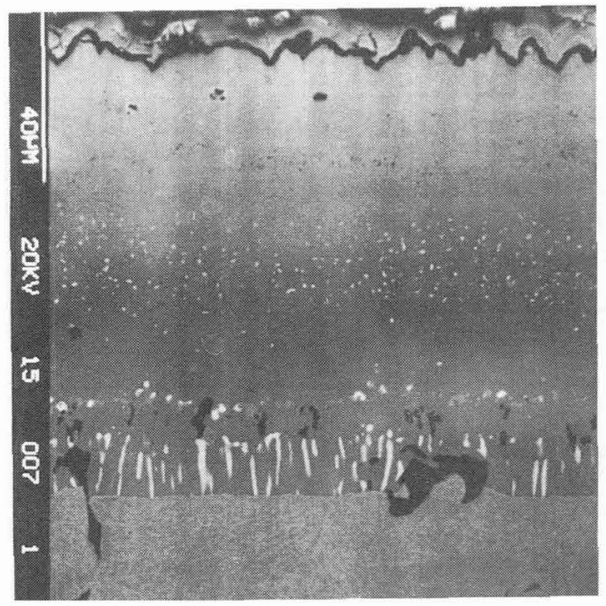

Fig. 1

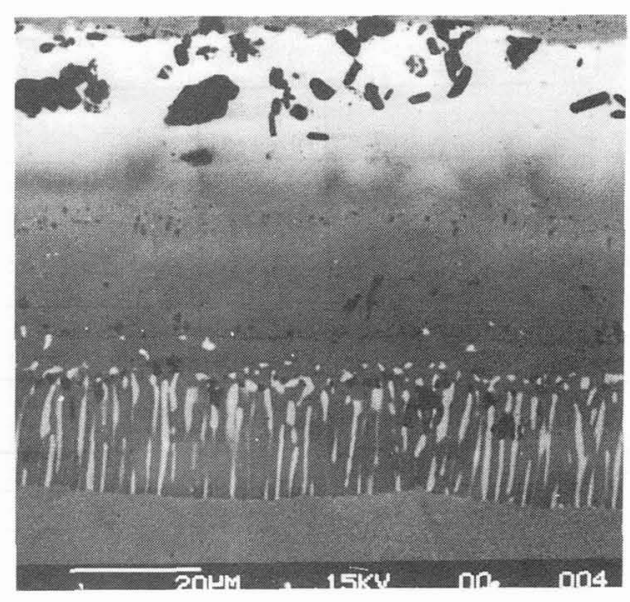

Fig. 2

Fig. 1. - Pd modified H.A. aluminide coating on IN100; metallographic cross section Scanning electron microscopy; backscattered electron image.

Fig. 2. - Pd modified L.A. aluminide coating on IN 100.

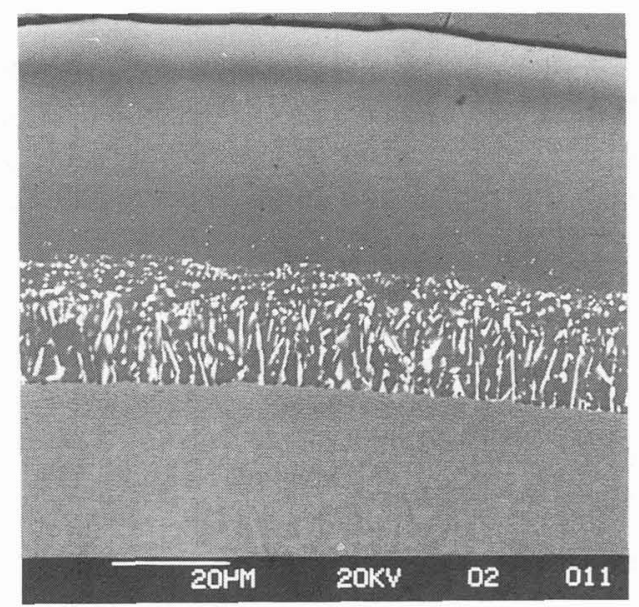

Fig. 3. - Pd modified SNECMA vapor phase aluminizing on SRR99.

( $\mathrm{Ni}^{*}$ and $\mathrm{Co}^{*}$, represent elements which diffuse towards the coating surface). Similarly, for a given superalloy substrate, few differences in the structure of the coatings are observed when the aluminum activity of the cementation process is being varied.

As in the case of classical aluminizing treatments, coating formation seems to essentially result from two reactions:

- diffusion of nickel, cobalt, chromium etc. from the substrate to the surface (reaction (1)), leading to the formation of the internal layer, 


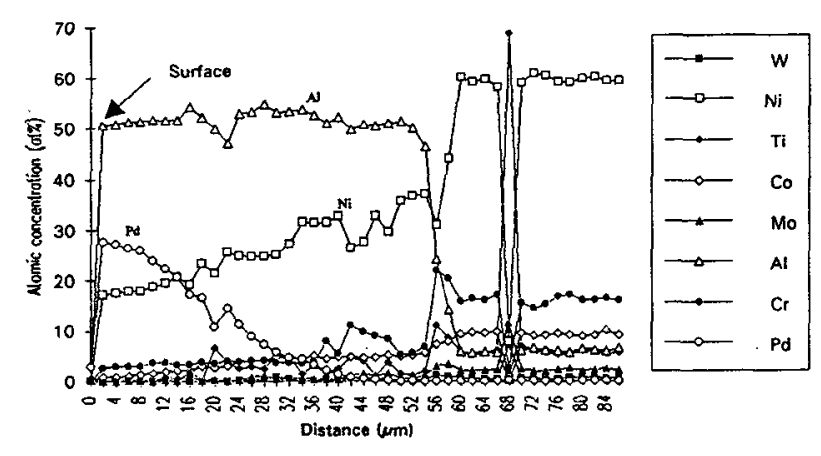

Fig. 4. - Pd modified H.A. aluminide coating on RENE80; concentration profiles obtained with the electron microprobe.

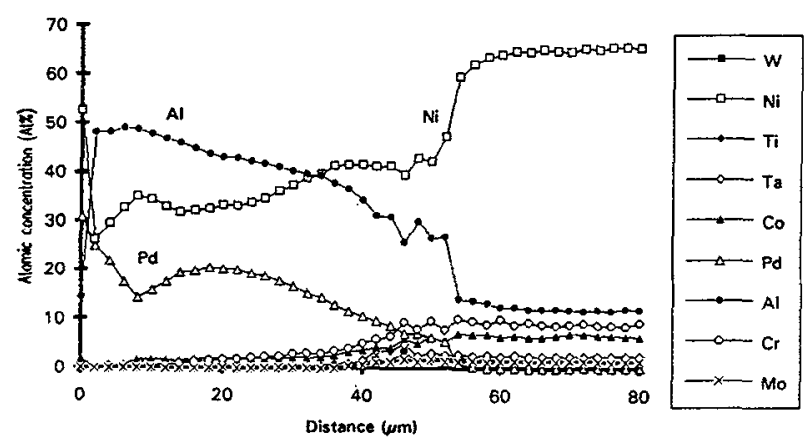

Fig. 5. - Pd modified L.A. aluminide coating on AMl; concentration profiles.

- reaction of these elements with aluminum supplied by the cement and formation of the external layer.

A careful examination of the distribution of palladium in the coatings shows however that it is strongly influenced by the aluminum activity of the cementation process. Microprobe analyses of the coatings show, indeed, that the shape of the palladium concentration gradients and the penetration of this element are quite different in H.A. and L.A. coatings (Figs. 4 to 6).

Figure 4 shows that the distribution of palladium in H.A. coatings is quite regular, with a monotonous concentration profile. Pd concentration is maximum at the surface (20 to $30 \%)$, and vanishes in a zone located ten to twenty micrometers away from the substrate, in the internal layer.

In L.A. coatings, the maximum palladium concentration is also observed at the surface, and its value is similar to that observed in H.A. coatings (about 30\%). Palladium is however less evenly distributed in L.A. coatings. Figures 5 and 6 show that in this case, the concentration profile of $\mathrm{Pd}$ in the external layer is not monotonous, but evidences a minimum located near the surface of the coating. Moreover, the palladium concentration do not fall to zero in the internal layer, but is approximately constant with values as high as $15 \%$. 


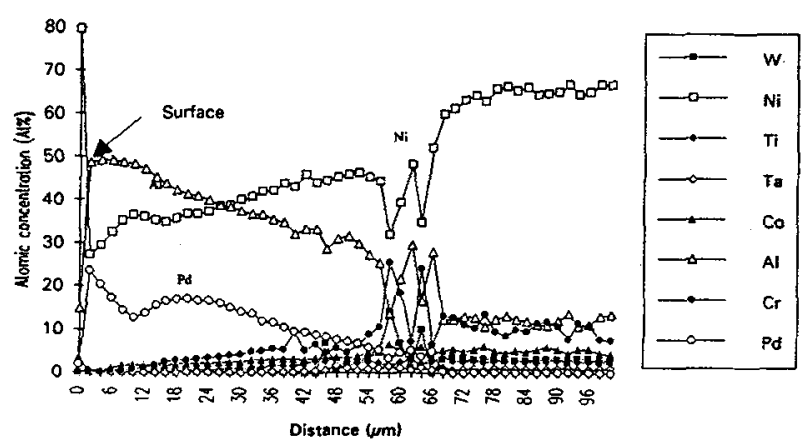

Fig. 6. - Pd modified vapor phase L.A. aluminide coating on SRR99; concentration profiles.

3.2 STUdY OF THE Ni-Pd-Al PHASE DIAGRAM. - The coating formation is obviously somewhat complicated by the presence of the Pd-Ni alloy undercoat. Interpretation of the structures obtained requires a good knowledge of the Ni-Pd-Al system. Few informations being available in the litterature about this phase diagram, it was decided to undertake a study restricted to the determination of the palladium solubility in the $\beta-\mathrm{NiAl}$ and $\mathrm{Ni}_{2} \mathrm{Al}_{3}$ phases. Elaboration of $\mathrm{NiPdAl}$ alloys was performed, corresponding to the two $\mathrm{NiAl}-\mathrm{PdAl}$ and $\mathrm{Ni}_{2} \mathrm{Al}_{3}$ $\mathrm{Pd}_{2} \mathrm{Al}_{3}$ pseudo-binary sections of the $\mathrm{Ni}-\mathrm{Pd}-\mathrm{Al}$ phase diagram. As could be predicted, considering the similarity between their structure (hexagonal, $\mathrm{D} 5_{13}$ type), the two $\mathrm{Ni}_{2} \mathrm{Al}_{3}$ and $\mathrm{Pd}_{2} \mathrm{Al}_{3}$ aluminides exhibit a total miscibility at the two temperatures studied (850 and 1100 ${ }^{\circ} \mathrm{C}$ ). Indeed, no two-phased domain could be found: X-Ray measurements evidenced a continuous evolution of the hexagonal cell parameters (Fig. 7).

In the case of the NiAl-PdAl section, the situation is very different, owing to the fact that, at the temperatures studied, $\mathrm{NiAl}$ and $\mathrm{PdAl}$ do not have the same crystalline structure. NiAl structure is isotypic to $\mathrm{CsCl}$ (cubic), whereas $\mathrm{PdAl}$ structure is trigonal below $1125^{\circ} \mathrm{C}$, and can also be cubic (FeSi type) below $960^{\circ} \mathrm{C}$ (in the case of $\mathrm{Pd}$ rich compositions). X-ray diffraction has shown that the synthetized $\mathrm{PdAl}$ aluminide was trigonal and could dissolve up to $11 \%$ nickel. The solubility of palladium in the $\beta$-NiAl structure is much more important, since it can reach $35 \%$, with a corresponding $\mathrm{Ni}_{0.3} \mathrm{Pd}_{0.7} \mathrm{Al}$ formula.

These results indicate that the two-phase portion of the NiAl-PdAl section is probably very narrow. This is confirmed by microhardness measurements which show a sharp discontinuity between the two compositions corresponding to $\mathrm{Ni}_{0.3} \mathrm{Pd}_{0.7} \mathrm{Al}$ and $\mathrm{Ni}_{0.2} \mathrm{Pd}_{0.8} \mathrm{Al}$ formulas. Figure 8 shows that in the $\beta-(\mathrm{Ni}, \mathrm{Pd}) \mathrm{Al}$ domain, the microhardness value is about $400 \mathrm{~kg} / \mathrm{mm}^{2}$ and is quite independent on the palladium content. Trigonal ( $\mathrm{Pd}, \mathrm{Ni}) \mathrm{Al}$ alloys exhibit a similar behavior, but their mean microhardness value is much higher (about $850 \mathrm{~kg} / \mathrm{mm}^{2}$ ).

\section{Discussion.}

Despite the lack of experimental information concerning the intermediate steps of cementation treatments, it seems possible to propose mechanisms for coatings growth. Indeed, $\mathrm{Pd}$ being initially present in limited quantity at the surface of the superalloy substrates, it can be considered as a marker, although not inert since it dissolves in the two types of aluminides which can form during aluminizing. Its solubility in the $\mathrm{Ni}_{2} \mathrm{Al}_{3}$ and $\mathrm{NiAl}$ structures being 


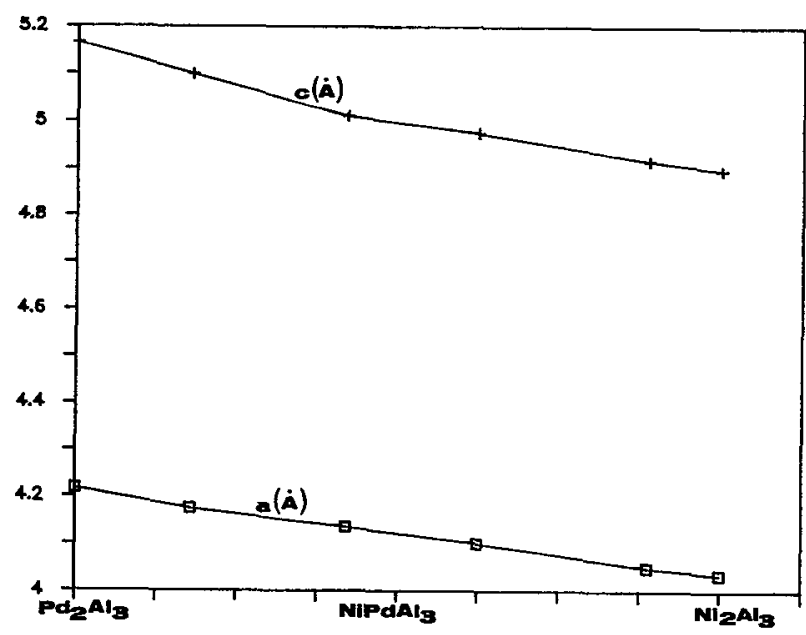

Fig. 7. - Evolution of the cell parameters in the $\mathrm{Ni}_{2} \mathrm{Al}_{3}-\mathrm{Pd}_{2} \mathrm{Al}_{3}$ pseudo-binary system.

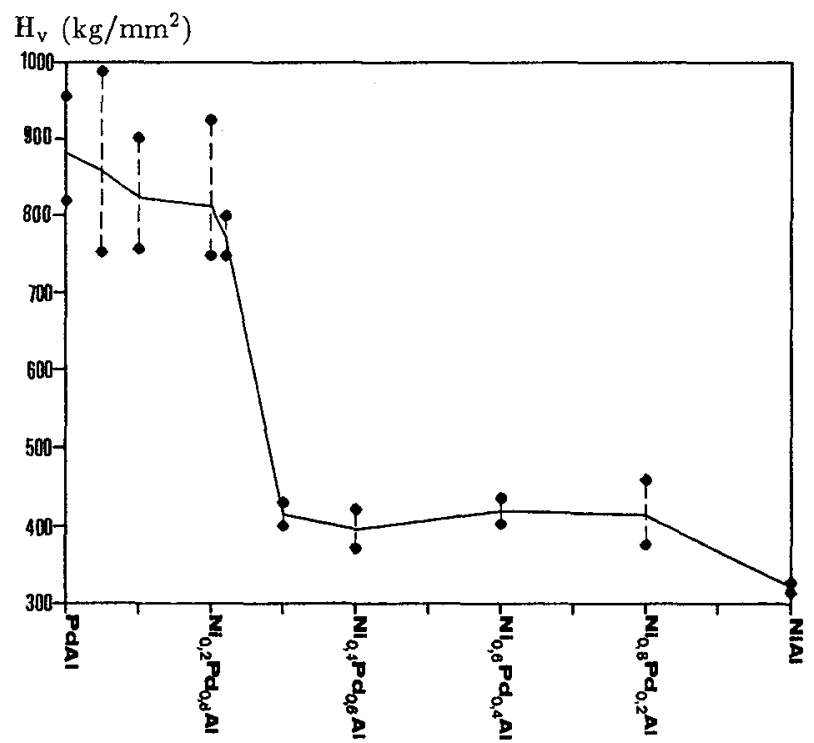

Fig. 8. - Evolution of the room temperature microhardness values $(\mathrm{load}=20 \mathrm{~g})$ in the NiAl-PdAl pseudo-binary system.

known, its concentration profiles can be used to interprete coating formation in the two cases studied.

4.1 LOW ACTIVITY COATINGS. - The formation of the coating should proceed in two consecutive steps. The first one corresponds to aluminizing of the PdNi undercoat, following:

$$
\mathrm{Pd}_{0.7} \mathrm{Ni}_{0.3}+\mathrm{Al} \rightarrow\left(\mathrm{Pd}_{0.7} \mathrm{Ni}_{0.3}\right) \mathrm{Al}
$$


(where $\mathrm{Pd}_{0.7}-\mathrm{Ni}_{0.3}$ is the atomic composition of a typical electrolytically deposited underlayer).

The study devoted to the determination of the Ni-Pd-Al phase diagram indicates that the structure of this ternary aluminide could be trigonal (this composition is just at the Pd solubility limit of cubic ( $\mathrm{Ni}, \mathrm{Pd}) \mathrm{Al}$ ). However the $\mathrm{Pd}$ concentration profiles in the coatings show that the maximum $\mathrm{Pd} / \mathrm{Ni}$ ratio observed is equal to 1.5 and not to 2.3 - as equation (2) would suggest - and so, no trigonal phase is being observed in aluminized samples. This limitation of the maximum palladium concentration observed in real coatings can easily be understood: before aluminizing, the samples are annealed 2 hours at $850^{\circ} \mathrm{C}$, to increase the adherence of the PdNi undercoat; diffusion of $\mathrm{Pd}$ towards the substrate can thus lower its superficial concentration in the undercoat. The aluminizing treatment can also have a similar effect. It is thus not too much suprising that from the onset of the cementation treatment, the ternary aluminide structure is cubic $(\mathrm{Pd} / \mathrm{Ni} \ll 2.3)$.

As soon as the undercoat has been aluminized, the second step initiates. $\mathrm{Al}$ and Ni may diffuse through the $\beta$-(Pd, Ni)Al layer, the final location of this layer being a qualitative indicator of the relative magnitudes of the opposite $\mathrm{Ni}$ and $\mathrm{Al}$ fluxes. Three hypotheses are conceivable, each leading to a particular Pd distribution in the coatings.
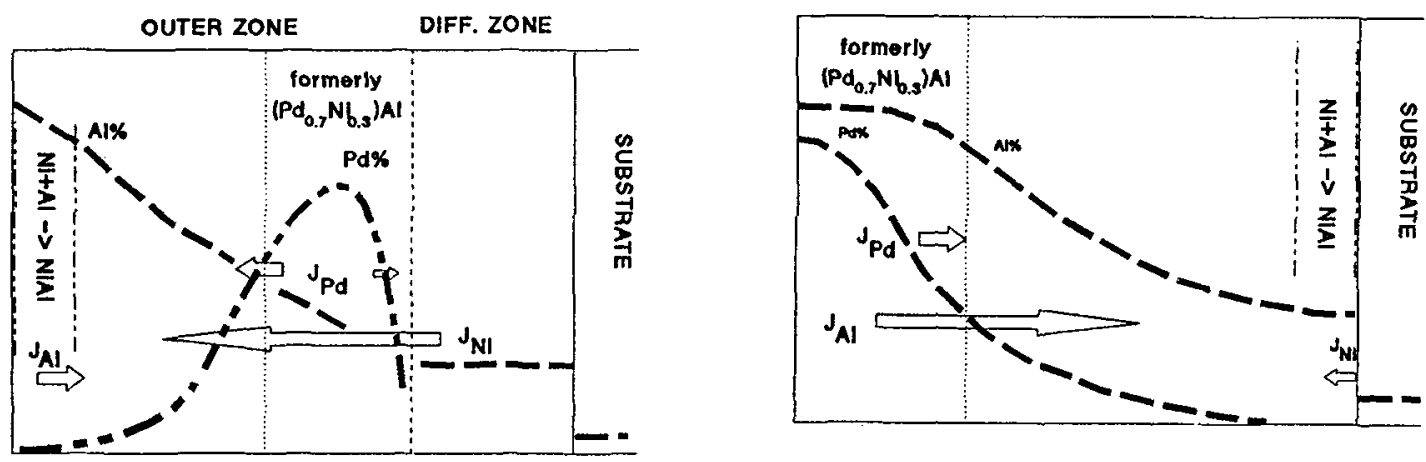

a)

b)

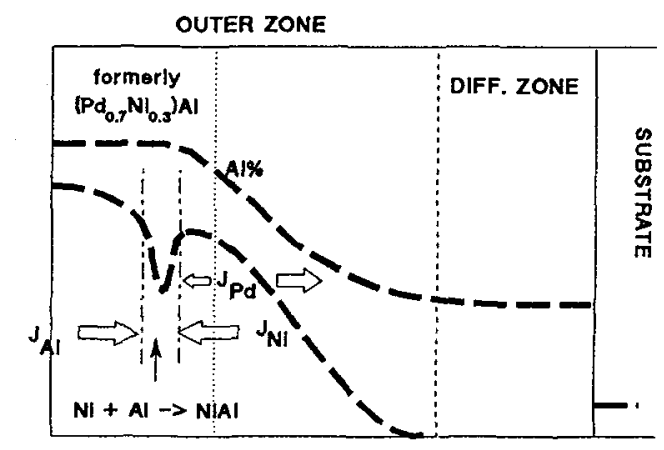

c)

Fig. 9. - Schematic representation of the formation of a Pd modified L.A. coating: a) $J_{\mathrm{Ni}} \gg J_{\mathrm{Al}}$; b) $J_{\mathrm{Al}} \gg J_{\mathrm{Ni}} ;$ c) $J_{\mathrm{Al}} \simeq J_{\mathrm{Ni}}$. 
If the outward nickel flux is much higher than the opposite inward aluminum flux, the initial ( $\mathrm{Pd}, \mathrm{Ni}) \mathrm{Al}$ layer should stay near the diffusion zone, since aluminide formation predominantly occurs at its outer surface (Fig. 9a). If, on the contrary, the aluminum inward flux is greater than $\mathrm{Ni}$ outward flux, the (Pd, Ni)Al initial layer should be observed at the surface of the coating, as shown on figure $9 \mathrm{~b}$. The actual situation lies in fact in between those two extreme cases (Fig. 9c). $\mathrm{Al}$ and $\mathrm{Ni}$ fluxes are opposite in direction and of the same order of magnitude; both contribute significantly to coating formation. In this context, the cross-over between the two fluxes is materialized by the minimum observed in the Pd concentration profile (Figs. 5 and 6 ). This minimum is all the more shifted towards the substrate that aluminum activity in the cementation process is high. Coatings micrographs (Figs. 1 and 3 ) and concentration profiles in the case of pack and vapor phase cementation processes (Figs. 5 and 6) show that the Pd concentration minimum in the vapor phase L.A. coating is closer to the surface than in the pack L.A. coating. This clearly proves that the former is indeed a lower activity process than the latter. This difference could be explained by the extra contribution of cement grains to $\mathrm{Al}$ transport in the case of pack processes.

4.2 High ACTIVITY COATINGS. - As in the case of L.A. coatings, the cementation should occur in successive steps. Considering the nature of the H.A. process, they are however more numerous.

The first step is H.A. aluminizing of the PdNi undercoat which, considering the results of the study of the $\mathrm{Ni}_{2} \mathrm{Al}_{3}-\mathrm{Pd}_{2} \mathrm{Al}_{3}$ section of the NiPdAl phase diagram, should lead to the formation of a ternary $(\mathrm{Pd}, \mathrm{Ni})_{2} \mathrm{Al}_{3}$ aluminide with an hexagonal crystalline structure. The corresponding reaction could be:

$$
2 \mathrm{Pd}_{(1-x)} \mathrm{Ni}_{x}+3 \mathrm{Al} \rightarrow \text { hex }\left[\operatorname{Pd}_{(1-x)} \mathrm{Ni}_{x}\right]_{2} \mathrm{Al}_{3}
$$

Once the undercoat is aluminized, H.A. aluminizing of the superalloy substrate should occur. Since it is a high aluminum activity process, aluminum inward diffusion is predominant and consequently the initial ( $\mathrm{Pd}, \mathrm{Ni}_{2} \mathrm{Al}_{3}$ must stay at the surface of the coating (Fig. 10a). The last step is diffusion annealing: aluminum from the superficial $\mathrm{Ni}_{2} \mathrm{Al}_{3}$ type layer diffuses

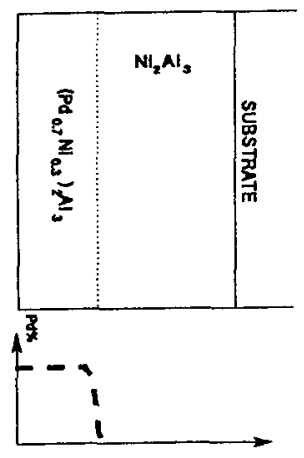

a)

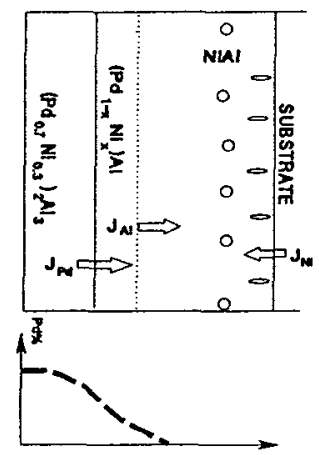

b)

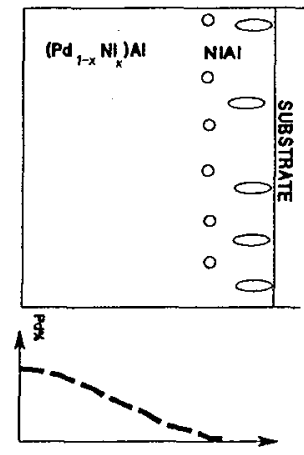

c)

Fig. 10. - Schematic representation of the formation of a Pd modified H.A. coating; coating and corresponding Pd concentration gradient: a) After aluminizing treatment; b) to d) evolution of the coating during post-aluminizing diffusion annealing. 
towards the substrate, whereas nickel, cobalt etc. diffuse from the substrate towards the surface. The initial ( $\mathrm{Pd}, \mathrm{Ni})_{2} \mathrm{Al}_{3}$ being located at the surface of the hexagonal aluminide phase is transformed last. Before this reaction occurs, Pd can diffuse towards the substrate, and the concentration of this element is thus lower in the end than the composition of the initial undercoat layer could have suggested. This last step is schematically illustrated in figures $10 \mathrm{~b}$, c, which depict the suggested evolution of the palladium distribution during H.A. coating annealing. One can thus observe that palladium must again be concentrated at the surface of the coating but that, contrarily to the case of L.A. coatings, its distribution cannot evidence any concentration minimum. Moreover, interdiffusion first concerning the substrate and a palladium-free $\mathrm{Ni}_{2} \mathrm{Al}_{3}$ type aluminide, the main part of the diffusion zone of the $\mathrm{NiAl}$ coating must be palladium-free, which is confirmed by our observations.

\section{Conclusion.}

Pd-Ni undercoat causes weight enhancement during aluminizing treatment. This is mostly due to the undercoat transformation corresponding to the first step of the cementation processes.

Palladium concentration profiles provide qualitative indications concerning the overall "activity" of $\mathrm{Al}$ in the aluminizing process. $\mathrm{Pd}$, if present at a sufficient level, enhances aluminum diffusion in the beta phase.

In the case of a L.A. process, a consequence of the increase of $\mathrm{Al}$ diffusion flux is the location of $\mathrm{Ni}-\mathrm{Al}$ reaction zone inside the coating, and not at the gas/metal interface like it is the case with simple aluminides. $\mathrm{Ni}$ and $\mathrm{Al}$ fluxes meeting to form "pure" $\mathrm{NiAl}$, this zone is characterized by a low palladium level. In this particular case, the palladium concentration profile thus evidences a minimum, the position of which is dictated by the relative magnitudes of the nickel and aluminum fluxes.

The Pd concentration profiles differ in shape for H.A. processes. There is no local minimum since in this case the $\mathrm{Pd}$ containing $\mathrm{Ni}_{2} \mathrm{Al}_{3}$ type phase is first rejected at the surface of the coating. It is thus converted into NiAl only at the end of the annealing time, and the palladium concentration gradient is monotonous.

The thermodynamic and kinetic factors which account for the overall increase of the Al flux during coating elaboration, would probably be also favourable to protective alumina scale formation during long-time exposure to oxidizing atmospheres at high temperature.

The study of the ternary Ni-Pd-Al phase diagram has also pointed out that modifying aluminide coatings with palladium can be advantageous in terms of mechanical properties, compared to platinum. The main limitation to the use of platinum is indeed the brittleness of the coatings, due to the formation of the $\mathrm{PtAl}_{2}$ phase. Such a phenomenon cannot occur with palladium, if the cementation process is adapted to produce coatings whose maximum palladium concentration does not exceed 35\%. Microhardness measurements show that, if this limit value is respected, the coating mechanical properties can be unaffected by palladium.

\section{References}

[1] LeHnert G., Meinhardt H.W., Electrodeposition Surf. Treat. 1 (1972) 189.

[2] STREIFF R., BOONE D.H., Reactivity of Solids (Elsevier, Amsterdam, 1972) p. 195. 
[3] Wood J.H., Goldman E.H., Superalloys II, G.T. Sims, N.S. Stoloff, W.C. Hagel Eds. (J. Wiley, N.Y. 1987) p. 359.

[4] Petitt F.S., Goward G.W., Superalloys Source Book, M.J. Donachie Ed. (ASM, 1984) p. 170 .

[5] STREIFF R., BoONE D.H., J. Mater. Eng. 10 (1988) 15.

[6] JACKSON M.R., RAIRDEN J.R., Metall. Trans. A 8 (1977) 1697.

[7] TAWANCY H.M., AbBas N.M., Rhys-Jones T.N., Surf. Coatings Technol. 49 (1991) 1.

[8] Alpérine S., Steinmetz P., Josso P., Costantini A., Mater. Sci. Eng. A 120/121 (1989) 367.

[9] Alpérine S., Steinmetz P., Costantini A., Josso P., Surf. Coatings Technol. 43/44 (1990) 347.

[10] Alpérine S., Steinmetz P., Costantini A., Josso P., Surf. Coatings Technol. 43/44 (1990) 500.

[11] Mévrel R., Duret C., Pichoir R., Mater. Sci. Technol. 2 (1986) 201.

[12] Gaugé G., Morbioli R., Proc. High Temperature Protective Coatings (Warrendale, PA, 1983) (The Metallurgical Society of AIME, Atlanta, GA, 1983) p. 13. 